\title{
Enzyme Activity of the Mitochondrial Respiratory Chain in Meishan Pigs
}

\author{
Hitoshi Mikami, Akira Onishi, Masanori Komatsu \\ and Tomiji Akita \\ National Institute of Animal Industry, Tsukuba \\ Norinkenkyudanchi, Ibaraki-ken 305
}

(Received May 11, 1989)

\begin{abstract}
The enzyme activity of hepatic mitochondria from Meishan was compared with those of Landrace, Large White and Duroc of $90 \mathrm{~kg}$ in weight. Although there were no significant breed differences in succinate-cytochrome $c$ reductase (complexes II and III), cytochrome c oxidase (complex IV) and NADH oxidase, which measures the entire respiratory chain from $\mathrm{NADH}$ to $\mathrm{O}_{2}$, Meishan showed the activity of NADH-ferricyanide reductase (complex I) to be $17-24 \%$ less than that in the other breeds. Meishan required a longer time period to reach a weight of $90 \mathrm{~kg}$ than the other breeds, but changes in NADH-ferricyanide reductase with ageing were not observed. Since seven subunits of complex I were encoded by mitochondrial DNA and Meishan and European breeds have different restriction enzyme cleavage patterns of mitochondrial DNA, the differences in the activities of Meishan and other breeds may possibly be associated with variation in mitochondrial DNA. The inheritance mode of NADH-ferricyanide reductase activity is now being investigated.
\end{abstract}

Jpn. J. Zootech. Sci, $60(9): 874-879,1989$

Key words : mitochondrial enzyme, breed difference, Meishan, pig

The Meishan is a native breed, originating from the Taihu Lake region in the lower Changjiang River valley ${ }^{1}$. The restriction enzyme cleavage patterns of mitochondrial DNA (mtDNA) of this breed differ from those of European breeds ${ }^{2)}$. MtDNA in mammalian cells encodes 13 polypeptides known to be components of the enzyme complexes of the mitochondrial membrane ${ }^{3-8)}$. Thus, variation in mtDNA may likely have effect on the energy metabolism of animal cells. Recently, we found that part of the activity of cytochrome $c$ oxidase, complex IV of the respiratory chain, is maternally inherited in mice ${ }^{9)}$.

In this paper, we compared several enzyme activities of the mitochondrial respiratory chains of Meishan, Landrace, Large White and Duroc to examine the possibility of maternal inheritance of mitochondrial energy metabolism.

\section{Materials and Methods}

Three boars and seven gilts of Meishan were supplied to Ibaraki Branchi, Shirakawa Livestock Breeding Station from China in 1986. We obtained their progenies in 1987 and bred them in the Swine Management Section of the National 
Institute of Animal Industry. Liver samples of Meishan were obtained from their next generation and those of Landrace, Large White and Duroc pigs, from herds in the Swine Management Section and Ibaraki Prefectural Experiment Station of Swine.

Twelve pigs of each breed, weighing about $90 \mathrm{~kg}$, were examined for breed differences in enzyme activity. Ageing effects were also studied using 36 Meishan pigs ageing from 7 to 38 weeks. Essentially the same numbers of females and castrated males were used. Since sex differences in enzyme activity were not significant (Table 1), data of both sexes were analyzed together.

Mitochondria were isolated from fresh livers. A $10 \%$ tissue homogenate was prepared with a Potter-Elvehjem homogenizer $(50 \mathrm{ml})$ in a buffer containing $0.25 \mathrm{M}$ sucrose, $3 \mathrm{mM}$ HEPS, $0.5 \mathrm{mM}$ EGTA. ( $\mathrm{pH} 7.4$ ). After removal of nuclei and cell debris by centrifugation at $700 \times \mathrm{g}$ for $10 \mathrm{~min}$, the mitochondria were isolated by centrifugation at $7,000 \times \mathrm{g}$ for $10 \mathrm{~min}$ and washed twice. The final pellets were resuspended in a homogenizing buffer at a protein concentration of $10-20 \mathrm{mg} / \mathrm{ml}$ and stored $-80^{\circ} \mathrm{C}$.

Cytochrome c oxidase and NADH oxidase activities were measured in freezethawed mitochondria. On the day of assay, the suspension was thawed and adjusted to a protein concentration of $1 \mathrm{mg} / \mathrm{ml}$ in the homogenizing buffer. $\mathrm{NADH}-$ ferricyanide reductase and succinate-cytochrome c reductase activities were measured in submitochondrial particles. For preparation of mitochondrial particles, the suspension was thawed and sonicated by a sonifer (Tosho Denki Co., Model UCD-130) for 5 min at one-minute intervals. The unbroken mitochondria were removed by centrifugation at $18,000 \times \mathrm{g}$ for $10 \mathrm{~min}$ and submitochondrial particles sedimented at $150,000 \times \mathrm{g}$ for $45 \mathrm{~min}$. The particles were resuspended in the homogenizing buffer to a protein concentration of $1 \mathrm{mg} / \mathrm{ml}$. Protein was determined by the method of Bradford ${ }^{10)}$ using the reagent of Bio-Rad Protein Assay with bovine serum albumin as the standard after diluting the specimens with $0.1 \mathrm{~N} \mathrm{NaOH}$ solution.

All spectrophotometric assays were carried out at $30^{\circ} \mathrm{C}$ at a final volume of

Table 1. Enzyme activities of mitochondrial respiratory chain of male and female Meishan and Landrace pigs

\begin{tabular}{lllc}
\hline \multirow{2}{*}{ Breed } & \multicolumn{2}{c}{ Enzyme } & \multicolumn{2}{c}{ Specific activity* } \\
\cline { 3 - 4 } & NADH-ferricyanide reductase & Male & Female \\
\hline \multirow{3}{*}{ Meishan } & $5.371 \pm 0.419^{* *}$ & $5.246 \pm 0.466$ \\
& Succinate-cytochrome c reductase & $0.385 \pm 0.180$ & $0.318 \pm 0.128$ \\
& Cytochrome c oxidase & $1.078 \pm 0.086$ & $1.006 \pm 0.110$ \\
& Rotenone-sensitive NADH oxidase & $0.046 \pm 0.010$ & $0.044 \pm 0.009$ \\
\hline \multirow{3}{*}{ Landrace } & NADH-ferricyanide reductase & $6.629 \pm 0.765$ & $6.903 \pm 0.974$ \\
& Succinate-cytochrome c reductase & $0.332 \pm 0.099$ & $0.300 \pm 0.110$ \\
& Cytochrome c oxidase & $1.030 \pm 0.073$ & $1.041 \pm 0.181$ \\
& Rotenone-sensitive NADH oxidase & $0.045 \pm 0.008$ & $0.043 \pm 0.010$ \\
\hline
\end{tabular}

*Enzyme activities are calculated as $\mu$ moles of substrate reduced or oxidized per min per mg of protein.

**Mean \pm S. D. for 7 pigs. 
Mikami, Onishi, Komatsu and Akita

$2.0 \mathrm{~m} l$. NADH-ferricyanide reductase was assayed by the method of MALCzEwsKI and WHITFIELD $^{11)}$ except that the final concentration of $\mathrm{K}_{3} \mathrm{Fe}(\mathrm{CN})_{6}$ was $0.5 \mathrm{mM}$. The reaction was started by adding $25 \mu \mathrm{l}$ of submitochondrial particle suspension to the reaction mixture. Succinate-cytochrome $c$ reductase was measured as described by TISDALE ${ }^{12)}$. The reaction mixture contained $50 \mu l$ of a submitochondrial particle suspension. Cytochrome $c$ oxidase was assayed by a modification of the method of WHARTON and TzagolofF ${ }^{13)}$. The reaction was initiated by adding $20 \mu l$ of a freeze-thawed mitochondria suspension to the reaction mixture containing $1.0 \mathrm{mg}$ ferrocytochrome c.

NADH oxidase was analyzed by the method of GreEN and ZIEGLER ${ }^{14)}$ with modification. $150 \mu l$ of a freeze-thawed mitochondria suspension were incubated with the assay mixture for $4 \mathrm{~min}$ at $30^{\circ} \mathrm{C}$. The reaction was initiated by adding $100 \mu l$ of $2 \mathrm{mM} \mathrm{NADH}$ and $20 \mu l$ of $1.0 \%$ cytochrome c.

The same number of samples was used each day for each breed and two readings were taken for each sample.

\section{Results and Discussion}

Table 2 shows the activities of $\mathrm{NADH}$-ferricyanide reductase, succinatecytochrome $\mathrm{c}$ reductase, cytochrome c oxidase and NADH oxidase for Meishan and the other three breeds. NADH-ferricyanide measured the first part of the respiratory

Table 2. Enzyme activities of mitochondrial respiratory chain of four pig breeds

\begin{tabular}{clc}
\hline \multicolumn{1}{c}{ Enzyme } & Breed & Specific activtity* \\
\hline & Meishan & $5.233 \pm 0.586^{* *, a}$ \\
NADH-ferricyanide reductase & Landrace & $6.883 \pm 0.779^{\mathrm{b}}$ \\
& Large White & $6.800 \pm 1.258^{\mathrm{b}}$ \\
& Duroc & $6.260 \pm 0.688^{\mathrm{b}}$ \\
\hline & Meishan & $0.366 \pm 0.113^{\mathrm{a}}$ \\
Succinate-cytochrome c reductase & Landrace & $0.357 \pm 0.071^{\mathrm{a}}$ \\
& Large White & $0.308 \pm 0.057^{\mathrm{a}}$ \\
& Duroc & $0.343 \pm 0.060^{\mathrm{a}}$ \\
\hline & Meishan & $1.046 \pm 0.120^{\mathrm{a}}$ \\
& Landrace & $1.037 \pm 0.124^{\mathrm{a}}$ \\
& Large White & $1.091 \pm 0.091^{\mathrm{a}}$ \\
& Duroc & $0.999 \pm 0.125^{\mathrm{a}}$ \\
\hline & Meishan & $0.046 \pm 0.008^{\mathrm{a}}$ \\
Rotenonome c oxidase & Landrace & $0.043 \pm 0.009^{\mathrm{a}}$ \\
& Large White & $0.043 \pm 0.006^{\mathrm{a}}$ \\
& Duroc & $0.048 \pm 0.008^{\mathrm{a}}$ \\
\hline
\end{tabular}

*Enzyme activities are calculated as $\mu$ moles of substrate reduced or oxidized per min per $\mathrm{mg}$ of protein.

**Mean \pm S. D. for 12 pigs.

${ }^{a, b}$ Column values with different subscripts differ significantly $(p<0.001)$. 
chain (complex I) using ferricyanide as an artificial acceptor. Meishan showed lower activity of NADH-ferricyanide reductase than did Landrace, Large White or Duroc. All differences in Meishan and the other breeds were significant $(p<0.001)$. No significant differences were observed among Landrace, Large White and Duroc.

Succinate-cytochrome c reductase measured complex II and III together, and cytochrome c oxidase, the terminal portion (complex IV) of the respiratory chain. There were no significant breed differences in these enzyme activities.

Rotenone-sensitive NADH oxidase activity was calculated from the activity differences in the absence and presence of rotenone. Rotenone is a specific inhibitor of the respiratory chain that interupts electron flow between NADH dehydrogenase and ubiquinone, and rotenone-sensitive $\mathrm{NADH}$ oxidase was used to measure the entire respiratory chain from $\mathrm{NADH}$ to $\mathrm{O}_{2}$. There were no significant differences in the activity among the breeds.

In this study, we found NADH-ferricyanide reductase activity of Meishan to be lower than those of Landrace, Large White and Duroc. Measurement for each breed was made with the live weight being $90 \mathrm{~kg}$ in each case. Since the growth rate of Meishan is clearly less than that of European breeds, we investigated whether differences in NADH-ferricyanide reductase activity between Meishan and other breeds would be due to differences in the age at the time of slaughtering. Fig. 1 shows ageing changes in NADH-ferricyanide reductase activity of Meishan from 7 to 38 weeks of age. The regression coefficient of the activity for weeks of age was not significant and age-related changes could be ignored.

MtDNA in animals is inherited maternally and encodes 13 polypeptides known to be components of enzyme complexes of the mitochondrial membrane ${ }^{3-8)}$. Studies on Chinese hamster mutant cells have demonstrated that decrease in the activities of complex I and cytochrome c oxidase in the mutant are due to reduction in the levels of mitochondrially coded subunits ${ }^{11,15)}$. We found that the $R R$ mouse strain, having unique restriction enzyme cleavage patterns of mtDNA, showed lower activity of

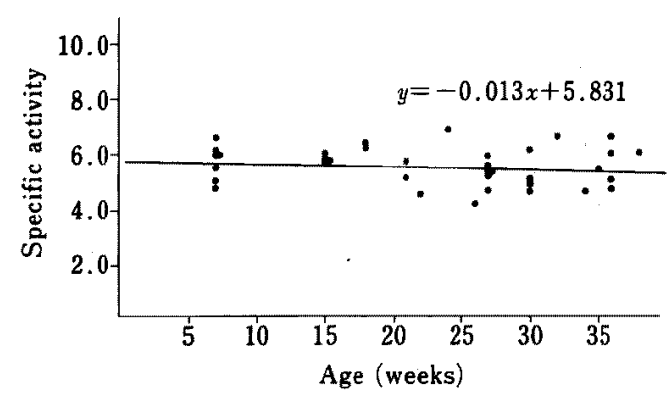

Fig. 1. NADH-ferricyanide reductase activity in mitochondria from Meishan pigs at different ages. Each point represents one individual. Activity is expressed as $\mu$ moles of ferricyanide reduced per $\mathrm{min}$ per $\mathrm{mg}$ of protein. 
cytochrome c oxidase of mitochondria than $\mathrm{C} 57 \mathrm{BL} / 6$ and $\mathrm{BALB} / \mathrm{C}$ strains, and that this was maternally inherited to some degree ${ }^{9)}$. Although variation in mitochondrial respiratory activity associated with performance traits have been reported in sheep ${ }^{16)}$, swine ${ }^{17)}$ and cattle ${ }^{18)}$, to our knowledge, no study has been conducted on phenotypic variation in mitochondrial enzyme activity associated with mtDNA polymorphism in livestock.

W ATANABE et al. ${ }^{19,20)}$ found the restriction enzyme cleavage patterns of Japanese wild pigs and Taiwan native breeds to differ from those of European breeds and consider the pigs to possibly have derived from two different maternal origins, European and Asian wild pigs. Our previous paper ${ }^{2)}$ indicated differences in restriction enzyme cleavage patterns of Chinese three breeds, Meishan, Jinhua and Minzu, and European breeds. The patterns of these breeds are probably the same as those of the Asian type described by Watanabe et al. ${ }^{20)}$. Watanabe et al. ${ }^{19)}$ found Large White to have the patterns of both Asian and European types, but we have yet to find Asian-type patterns in our Large White specimens.

Meishan showed 17-24\% lower activity than Landrace, Large White and Duroc. Complex $I$ is comprised of more than 20 different polypeptide subunits ${ }^{21)}$, seven of which are encoded by mtDNA. Since mtDNA encodes 13 polypeptides, almost $60 \%$ of the polypeptide coding capacity of mtDNA is utilized for the assebly of complex I. Differences in NADH-ferricyanide reductase activity observed for Meishan and other breeds may be possibly associated with mtDNA variation. A study is now being conducted on the inheritance mode of activity by the reciprocal crossing of Meishan and Landrace.

\section{Acknowledgements}

The authors thank Mr. T. ARAI and the staff of the Ibaraki Prefectural Experiment Station of Swine for providing fresh pig livers.

\section{References}

1) Cheng, P.L., Pig News and Information, 4: 407-425. 1983.

2) Mikami, H., A. Onisahi, K. Komatsu, T. Otani, T. Seki and S. Igarashi. Jpn. J. Swine Science, 25 : 181-185. 1988.

3) Anderson, S., A.T. Bankier, B.G. Barrell, M.H.L. de Bruijn, A.R. Coulson, J. Drouin, I.C. Eperon, D.P. Nierlich, B.A. Roe, F. SAnger, P.H. Schreier, A.J.H. Smith, R. Staden and I.G. Young, Nature, $290: 457-465.1981$.

4) Anderson, S., M.H.L. de Bruijn, A.R. Coulson, I.C. Eperon, F. Sanger and I.G. YounG, J. Mol. Biol., 156: 683-717. 1982.

5) Bibb, M.J., R.A. Van Etten, C.T. Wright, M.W. Walberg and D.A. Clayton, Cell, $26: 167-180.1981$.

6) Chomyn, A., P. Mariottoni, M.W.J. Cleeter, C.I. Ragan, A. Matsuo-Yagi, Y. Hatefi, R.F. Doolitrle and G. Atrardi, Nature, 314:592-597. 1985.

7) Chomyn, A., P. Mariottoni, M.W.J. Cleetrer, C.I. Ragan, R.F. Doolittle, A. Matsuo-Yagi, Y. Hatefi and G. AtTARd, in Achievements and Perspectives of Mitochondrial Research, vol. II (Quagliariello, E., E.C. Slater, F. Palmieri, C. SAcCone and A.M. Kroon eds.), 259-275. Elsevier Science Publishers B.V., 1985. 
8) Comyn, A., M.W.J. Clemeter, C.I. Ragan, M. Riley, R.F. Doolittle and G. Attardi, Science, 234 : 614-618. 1986.

9) Mikami, H., A. Onishi and K. Komatsu, J. Hered., 80 : 132-136. 1989.

10) BradFord, M., Anal. Biochem., 72 : 248-254. 1976.

11) Malczewski, R.M. and C.D. Whitfield, J. Biol. Chem., 259: 11103-11113. 1984.

12) Tisdale, H.D., in Methods in Enzymology, vol. $X$ (Estabrook, R.W. and M.E. Pullman eds.), 213-215. Academic Press. New York. 1967.

13) Wharton, D.C. and A. Tzagoloff, in Methods in Enzymology, vol. X (Estabrook, R.W. and M.E. Pullman eds.), 245-250. Academic Press. New York. 1967.

14) GreEn, D.E. and D.M. ZIEGLER, in Methods in Enzymology, vol. VI (Estabrook, R.W. and M.E. Pullman eds.), 416-424. Academic Press. New York. 1967.

15) Malczewski, R.M. and C.D. Whitfield, J. Biol. Chem., 257: 8137-8142. 1982.

16) Wolants, M., V. Dzapo and R. Wassmuth, Z. Tierz. Zuchtungsbiol., 97: 37-49. 1980.

17) DzApo, V. and R. Wassmuth, Z. Tierz. Zuchtungsbiol., 100 : 280-295. 1983.

18) Brown, D.R., S.K. Denise and G. Mc Daniel, J. Anim. Sci., 66 : 1347-1354. 1988.

19) Watanabe, T., Y. Hayashi, W. Ogasawara and T. Tomita, Biochem. Genet., 23 : 105-113. 1985.

20) Watanabe, T., Y. Hayashi, J. Kimura, Y. Yasuda, N. Sartoh, T. Tomita and N. Ogasawara, Biochem. Genet., $24:$ 385-396. 1986.

21) Ragan, C.I., M.W.J. Cleeter, F.G.P. Earley and S. Patel, in Achievements and Perspectives of Mitochondril Research, vol. Il (QuAgliariello, E., E.C. Slater, F. Palmieri, C. Saccone and A.M. Kroon eds.), 61-71. Elsevier Science Publishers B.V., 1985.

\section{梅山豚のミトコンドリア呼吸鎖酵素活性}

\section{三上仁志・大西 彰・小松正憲・秋田富士}

農林水産省畜産試験場，茨城県筑波農林研究団地 305

梅山豚の肝臓から得たミトコンドリアの呼吸鎖酵素活 性をランドレース，大ヨークシャー、デュロックのあの と $90 \mathrm{~kg}$ 時に比較した。コハク酸チトクロム $\mathrm{c}$ 還元醉 菜（複合体 II， III)，チトクロム $\mathrm{c}$ 酸化酵素（複合体IV）, $\mathrm{NADH}$ から $\mathrm{O}_{2}$ までの呼吸鎖全体を測定する NADH 酸化醉菜に品種差は見られなかったが、 $\mathrm{NADHーフェリ}$ シアナイイド還元醅菜（複合体 I）で梅山豚は他の品種よ り 17-24\% 低い活性を示した，梅山豚は他の品種より明 らかに $90 \mathrm{~kg}$ に達する日歯が遅いが， $\mathrm{NADH}$ フェリ
シアナイド還元酵素の活性に加齢に伴う変化は観察され なかった．複合体Ｉはその7個のサプュニットがミトコ ンドリア DNAによりコードされ，梅山豚のミトコン ドリア DNAの制限酵素切断型がヨーロッパの品種と 異なるため, 梅山豚と他の品種間で観察された NADHフェリシアナイト僈元酵菜の差がミトコンドリア DNA の変異と関連している可能性がある. 我々は現在,この 醇素活性の遭伝様式を調查中である。

日畜会報，60 $(9): 874-879,1989$ 